\title{
Mangiferin ameliorates 6-hydroxydopamine- induced cytotoxicity and oxidative stress in ketamine model of schizophrenia
}

\author{
Vietla S. Rao ${ }^{1}$, Ana C. Carvalho ${ }^{1}$, Maria Teresa S. Trevisan², \\ Geanne M. Andrade ${ }^{1}$, Helio V. Nobre Júnior ${ }^{1}$, Manoel O. Moraes ${ }^{1}$, \\ Hemerson I. Magalhães H. Iury ${ }^{1}$, Talita C. Morais ${ }^{1}$, Flavia A. Santos ${ }^{1}$ \\ ${ }^{1}$ Department of Physiology and Pharmacology, Federal University of Ceará, Cel Nunes de Melo-1127, \\ Caixa Postal-3157, 60430-270 Fortaleza, CE, Brazil \\ ${ }^{2}$ Department of Organic and Inorganic Chemistry, Federal University of Ceara, Fortaleza, CE, Brazil
}

Correspondence: Vietla S. Rao, e-mail: vietrao@ufc.br ; viet_rao@yahoo.com.br

\begin{abstract}
:
Background: Accumulating evidence indicates that mangiferin (MGF), a natural xanthone, by virtue of its antioxidant and antiinflammatory properties is neuroprotective. Here we sought to verify the cytoprotective role of MGF on cultured rat primary mesencephalic cells exposed to 6-hydroxydopamine (6-OHDA) in vitro, and the MGFs anti-inflammatory potential in mouse model of ketamine-induced schizophrenia in vivo.

Methods: 3-(4,5-dimethylthiazol-2-yl)-2,5-diphenyltetrazolium bromide (MTT)-assay was performed to measure cell viability in mesencephalic cell cultures exposed to neurotoxin (6-OHDA, $40 \mu \mathrm{M})$. Schizophrenia was induced in mice by ketamine $(50 \mathrm{mg} / \mathrm{kg}$, ip, twice a day, for 7 days). The treatment effects of MGF ( $50 \mathrm{mg} / \mathrm{kg}$, po, for 7 days) were verified on locomotor behavioral changes in open-field test, and on the oxidant stress-related increase in lipid-peroxidation (malondialdehyde) and interleukin-6 (IL-6) levels in brain tissues.

Results: MGF $(10-100 \mu \mathrm{M})$ produced no per se effect on cell viability as measured by MTT assay, but significantly prevented the 6-OHDA-induced cell death in a concentration-dependent manner. Acridine orange/ethidium bromide (AO/EtBr) staining confirmed the absence of 6-OHDA-induced morphological changes characteristic of apoptosis/necrosis. In open-field test, ketamineinduced impaired locomotor activity and behavioral changes such as grooming and stereotyped but not rearing were effectively ameliorated by MGF pretreatment. Also, ketamine-associated increase in brain tissue levels of IL-6 and MDA were significantly lowered in MGF-pretreated mice.

Conclusion: Mangiferin has a neurocytoprotective role related, at least in part, to an antioxidant and anti-inflammatory mechanism, which could be explored for more effective therapies of schizophrenia and other neurodegenerative diseases.
\end{abstract}

Key words:

mangiferin, cytoprotection, mesencephalic cell culture, 6-OHDA, ketamine, oxidative stress

Abbreviations: $\mathrm{AO} / \mathrm{EtBr}$ - acridine orange/ethidium bromide, DMSO - dimethyl sulfoxide, FBS - fetal bovine serum, IL-6 interleukin-6, MDA - malondialdehyde, MEM - minimum essential medium, MGF - mangiferin, MTT - 3-(4,5-dimethylthiazol2-yl)-2,5-diphenyltetrazolium bromide, MW - molecular weight, 6-OHDA - 6-hydroxydopamine, PBS - phosphate buffer solution, PI - propidium iodide, SOD - superoxide dismutase, TBARS - thiobarbituric acid reactive substances

\section{Introduction}

The brain is susceptible to oxidative damage due to its high lipid content and oxygen consumption. Neurodegenerative diseases like Alzheimer, Parkinson, bipolar disorder, epilepsy and schizophrenia are problems of 
vast clinical importance. Free iron can react with $\mathrm{H}_{2} \mathrm{O}_{2}$ via the Fenton reaction, a primary cause of lipid peroxidation, and may be of particular importance for these disorders [1]. Schizophrenia is a severe brain disorder characterized by hallucinations, disordered thinking and deficiencies in cognition and it has been suggested that environmental factors combined with a genetic predisposition result in the manifestation of this disease [25]. Despite its high incidence in general population, lack of adequate understanding on the pathophysiology of schizophrenia makes the treatment options difficult. Extensive evidence indicates that the glutamatergic $N$-methyl-D-aspartate (NMDA) neurotransmission is highly disrupted resulting in severe cognitive dysfunction and this pathway seems to be highly deregulated in experimental models of schizophrenia that simulate the symptoms of schizophrenia $[6,11,28,35,43]$. Some other studies indicated brain histaminergic neuronal system involvement in the pathogenesis of schizophrenia based on the protection offered by histamine 3-receptor antagonists/inverse agonists in the established animal models of schizophrenia [29, 30].

Drugs used to treat schizophrenia include the older generation medications such as chlorpromazine, haloperidol, perphenazine and fluphenazine, which are known to cause extrapyramidal side effects. On the other side, the newer generation drugs including the atypical antipsychotics like clozapine, risperidone, olanzapine, quetiapine, and ziprasidone have little or no side effects. Due to the low acceptability of these synthetics, the search has been shifted to the natural products having antioxidant and anti-inflammatory properties, which can afford better health promoting effects, compared to synthetics.

Mangiferin (MGF), a naturally occurring glucosylxanthone (Fig. 1) commonly encountered in sev-

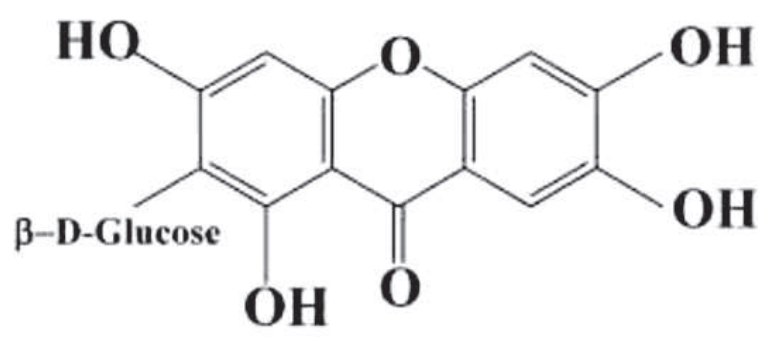

Fig. 1. Chemical structure of mangiferin (1,3,6,7-tetrahydroxyxanthone C2-D-glucoside) eral traditional medicinal plants [16] has been shown to produce multiple pharmacological effects that include antioxidant and anti-inflammatory [2, 4, 32], immunomodulatory $[20,26]$, and neuroprotective [9, 33 ] activities. There have been reports that MGF decreases glutamate-induced neurotoxicity and memory loss induced by scopolamine [23, 27, 39]. We previously demonstrated that MGF affords gastroprotection against absolute ethanol or indomethacin-induced gastric ulceration through an antioxidant mechanism [10]. Impaired antioxidant defenses are suggested to participate in the pathophysiology of schizophrenia and other neurodegenerative conditions. Altered superoxide dismutase (SOD) and increased lipid peroxidation, measured by the thiobarbituric acid reactive substances (TBARS/MDA), are increased in schizophrenic patients [17]. Besides, MGF has the iron complexing ability and can protect against $\mathrm{Fe}^{2+}$-citrate induced lipid peroxidation [3]. The neurotoxin 6-OHDA is well-known to cause neuronal death by a free radical-mediated mechanism as well as by inhibiting the mitochondrial complex I and IV [18]. As MGF has a wide spectrum of pharmacological activity including antioxidant and anti-inflammatory activity $[26,32]$ and accumulating evidence suggests that MGF is neuroprotective, the current study is aimed to examine the cytoprotective role of MGF against 6-OHDA-induced neurotoxicity in cultured rat primary mesencephalic cells and its beneficial effects in the mouse model of ketamine-induced schizhophrenia.

\section{Materials and Methods}

\section{Animals}

Male Swiss mice (7-8 weeks old, 20-25 g) and adult male/female Wistar rats (4-5 months old) obtained from the Central Animal House of Federal University of Ceará, were used. They were housed in environmentally controlled conditions $\left(23 \pm 2^{\circ} \mathrm{C}, 12\right.$-h lightdark cycle), with free access to standard diet (Purina Chow) and water ad libitum. Rats were mated to obtain rats on pregnancy and to collect embryonic mesencephalic cells, for in vitro studies. Mice were used for in vivo experiments aimed to study the effects of drugs in ketamine model of schizophrenia. The experimental protocols were approved by the Animal 
Care and Use Committee of the Federal University of Ceara in accordance with the ethical guidelines of the International Association for the Study of Pain (IASP).

\section{Chemicals}

Mangiferin (MGF) was extracted and isolated from the bark of Mangifera indica L. (Anacardiaceae) as per procedures reported earlier [10]. The isolated MGF was approximately of $95 \%$ purity [4] having the molecular weight (MW) 422.5 and melting point (m.p.) $271^{\circ} \mathrm{C}$. Minimum essential medium (MEM), trypsin, MTT [3-(4,5-dimethylthiazol-2-yl)-2,5-diphenyltetrazolium bromide], cytochalasin-B, propidium iodide (PI), ethidium bromide $(\mathrm{EtBr})$ and fetal bovine serum (FBS) were purchased from Sigma Chemical Co. (St. Louis, MO, USA). Acridine orange (AO) was purchased from BDH Chemicals Ltd., Poole, England and ketamine from Sigma-Aldrich (MO, USA). MGF was dissolved in $0.02 \%$ DMSO and diluted with MEM immediately before use. Other drugs were dissolved in physiological saline or distilled water. Drug concentrations were adjusted for in vivo treatments to give a volume of $10 \mathrm{ml} / \mathrm{kg}$. The dose/concentration selection for MGF and 6-OHDA or ketamine was based on our pilot studies or literature based [28, 37, 39].

\section{Cell culture}

Mesencephalic cell culture containing neuronal and non-neuronal cells were obtained from mesencephalicum of Wistar rat embryos at 17-20 days of pregnancy [12]. Cells were cultured in MEM supplemented with FBS (10\%), streptomycin $(100 \mathrm{mg} / \mathrm{ml})$, penicillin $(1,000 \mathrm{IU} / \mathrm{ml})$, actinomycin $\mathrm{C}(2.5 \mathrm{mg} / \mathrm{ml})$, glucose $(11 \mathrm{mM})$, glutamine $(2 \mathrm{mM})$, and sodium bicarbonate $(24 \mathrm{mM})$. Cultures were maintained at $37^{\circ} \mathrm{C}$ in humidified $5 \% \mathrm{CO}_{2}$ air atmosphere. Seven days after plating, cultures were reutilized for experimentation. Media were replaced every 2-3 days and cells were subcultured when $80-90 \%$ confluent. Cells were plated at a density of $5 \times 10^{4}$ cells per well using 96-well culture plates pre-coated with poly-lysine.

\section{Protective effect of MGF against cell death induced by 6-OHDA}

Mesencephalic cell culture plates having a cell density of $5 \times 10^{4}$ cells per well were pre-incubated with MGF in concentrations of 10,30 , and $100 \mu \mathrm{M}$ for $15 \mathrm{~min}$, prior to addition of 6-OHDA $(40 \mu \mathrm{M})$. Each concentration of MGF was tested in six replicates and repeated three times in separate experiments. Cell viability after exposure to 6-OHDA or MGF (10, 30, and $100 \mu \mathrm{M}$ ) alone, or in combination was determined in culture plates by MTT as described by Mosmann [36]. This method measures mitochondrial activity based on the reductive cleavage of yellow tetrazolium salt to a purple formazan compound by the dehydrogenase activity of intact mitochondria. Briefly, cells were washed once with PBS before the addition of $0.1 \mathrm{ml}$ of serum free medium containing MTT ( $1 \mathrm{mg} / \mathrm{ml})$ to each well. After incubation for $3 \mathrm{~h}$, the supernatant was removed and the formazan product obtained was dissolved in $1 \mathrm{ml}$ dimethyl sulfoxide (DMSO) with stirring for $15 \mathrm{~min}$ on a microtiter plate shaker and the absorbance was read at $550 \mathrm{~nm}$. The percentage of viable cells in each treatment group was determined by comparing their respective absorbance with that of control group.

In the analysis of MGF effect on apoptosis/necrosis induced by 6-OHDA, cell culture plates were divided into following groups: Group I, MGF $30 \mu \mathrm{M}$; Group II, 6-OHDA $40 \mu \mathrm{M}$; Group III, MGF + 6-OHDA cell cultures of this group were treated with MGF $30 \mu \mathrm{M}$ for $2 \mathrm{~h}$ followed by 6-OHDA $40 \mu \mathrm{M}$ for $3 \mathrm{~h}$. The cells were then allowed to grow for $24 \mathrm{~h}$. After this time, the cells were pelletted and each sample was mixed with $1 \mu$ l of aqueous acridine/ethidium bromide $(\mathrm{AO} / \mathrm{EtBr})$ solution $(100 \mu \mathrm{g} / \mathrm{ml}$ of each in PBS) just prior to fluorescence microscopy analysis and quantification (Olympus, Tokyo, Japan). Microscopic analysis was carried out to provide the cytomorphological evidence for normal, apoptotic and necrotic cells, differentiated by $\mathrm{AO} / \mathrm{EtBr}$ staining, which were expressed in $\%$ of total cells [34, 40]. At least three hundred cells per sample were analyzed.

The measurement of nitrate/nitrite concentration as an index of nitric oxide (NO) production in culture plates exposed to cytotoxin 6-OHDA (with or without MGF) was determined based on Griess reaction [19]. Briefly, $100 \mu \mathrm{l}$ of supernatant obtained from each culture plate was incubated at room temperature for 10 min with $100 \mu 1$ of Griess reagent [1\% sulfanila- 
mide in $1 \% \mathrm{H}_{3} \mathrm{PO}_{4} / 0.1 \% \mathrm{~N}$-(1-naphthyl)-ethylenediamine dihydrochloride $/ 1 \% \quad \mathrm{H}_{3} \mathrm{PO}_{4} /$ distilled water, $1: 1: 1: 1]$ or to $100 \mu \mathrm{l}$ of $\mathrm{NaNO}_{2}$ at concentrations ranging from 0.75 to $100 \mu \mathrm{M}$ (standard curve). For the blanks, $100 \mu \mathrm{l}$ of the Griess reagent was added to $100 \mu \mathrm{l}$ of the cell culture medium. The absorbance was measured with a reader plate at $560 \mathrm{~nm}$. The standard curve was used for the determination of nitrite concentrations in samples and expressed in $\mu \mathrm{M}$.

\section{Ketamine-induced schizophrenia in mice}

Schizophrenia was induced in Swiss male mice as described by Liu et al. [28]. Mice were divided into four groups ( $\mathrm{n}=8-10$ animals/group), Group I served as control and received DMSO ( $2 \%$ in distilled water) as vehicle. Group II animals were treated with ketamine (50 mg/kg, ip, twice a day for 7 consecutive days). Group III animals were subjected to pretreatment with MGF (50 mg/kg/day for 7 days, po, dissolved in vehicle $2 \%$ DMSO) followed by ketamine injections (as above). Group IV animals were treated with MGF alone (as above). Thirty minutes following the respective treatments on day-7, the animals were first subjected to open-field test to note the locomotor activity and behavioral changes. Thereafter, the animals were killed by cervical dislocation. Tissues from the whole brain were immediately excised and homogenized in Tris-HCl buffer $0.01 \mathrm{M}$ (pH 7.4) to get $10 \%$ homogenates. These were then stored in a freezer at $-70^{\circ} \mathrm{C}$ until use for the analysis of IL- 6 cytokine and to measure the levels of lipid peroxidation.

\section{Analysis of behavioral alterations in open-field test}

Thirty minutes following the last treatment on day-7, the animals from respective groups were subjected to open-field test. The open-field apparatus $(30 \times 30$ $\times 20 \mathrm{~cm}$ ) was made of acrylic with transparent walls and black flooring divided into nine squares of equal area. After one minute of acclimatization, each animal from respective treatment groups was evaluated over a 5 min period for the following parameters: number of squares crossed with all the four paws, number of grooming and rearing, and the stereotyped behaviors scored (0-6) according to Setler et al. [41] by a person unaware of the animal treatments.

\section{Analysis of cytokine IL-6 levels and lipid peroxidation in brain tissue}

IL-6 cytokine levels in whole brain tissue homogenates $(10 \%)$ were determined with the aid of enzyme immunoassay kit (eBioscience - Mouse IL-6 ReadySET-Go! Elisa Kit with pre-coated plates). The assay was performed according to manufacturer's instructions and the cytokine levels were expressed as $\mathrm{pg} / \mathrm{ml}$. Lipid peroxidation was measured in terms of malondialdehyde (MDA) content following the thiobarbituric acid method of Ohkawa et al. [38]. Thiobarbituric acid reacts with MDA to form a pink chromogen, which can be detected spectrophotometrically at $532 \mathrm{~nm}$. In brief, aliquots $(250 \mu \mathrm{l})$ of the homogenate obtained previously were put into test tubes and mixed with an equal volume of thiobarbituric acid $(1.2 \%)$. This mixture was brought to the water bath for $30 \mathrm{~min}$ at a temperature ranging from 95 to $100^{\circ} \mathrm{C}$ and then cooled to room temperature. The tubes were then centrifuged at $3,000 \times \mathrm{g}$ for $10 \mathrm{~min}$ to precipitate the protein. The absorbance of supernatants was measured at $532 \mathrm{~nm}$. The standard curve was obtained by serial dilutions $(1,0.5,0.25,0.12,0.06,0.03 \mathrm{mM})$ using a solution of MDA. The concentration of MDA was expressed as $\mathrm{nmol} / \mathrm{g}$ tissue.

\section{Statistical analysis}

Values were expressed as the means \pm SEM. The significance of the differences between treatments and respective controls was analyzed by one-way analysis of variance (ANOVA), followed by the Newman- Keuls multiple comparison test. A p value of 0.05 was considered statistically significant.

\section{Results}

\section{Effect of MGF on cytotoxicity induced by 6-OHDA in cell culture}

The various concentrations of MGF (10, 30 and $100 \mu \mathrm{M})$ did not have a significant impact on cell viability when mesencephalic cells were treated with it for $24 \mathrm{~h}$ (Fig. 2A). When cells were treated with 6-OHDA $(40 \mu \mathrm{M})$, cell viability was markedly reduced ( $p<0.01$ ), compared to vehicle-treated control. Incubation of cells with increasing concentra- 


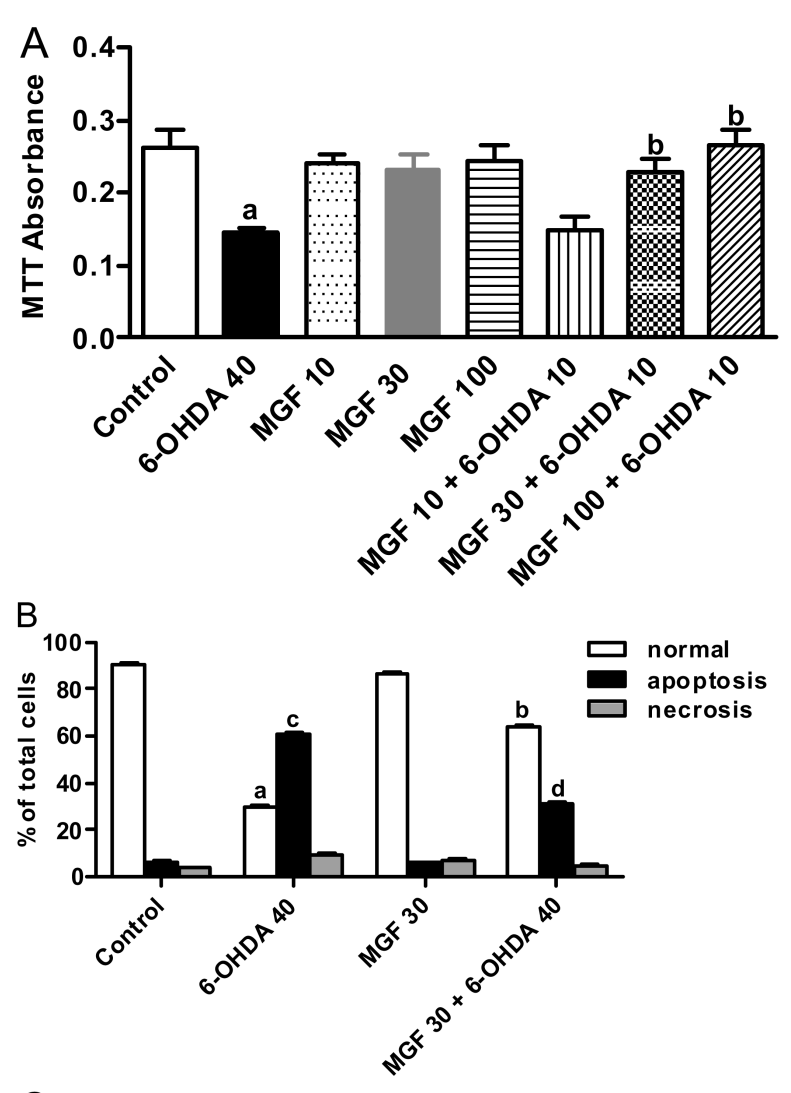

tions of MGF $(10,30$ and $100 \mu \mathrm{M})$ before exposure to $40 \mu \mathrm{M} 6-$ OHDA, a gradual and significant $(\mathrm{p}<0.01)$ increase in cell survival was observed at 30 and $100 \mu \mathrm{M}$, compared to control group of cells exposed to 6-OHDA alone. Maximum elevation in cell survival was apparent at $100 \mu \mathrm{M}$ MGF concentration.

\section{Fluorescence microscopy analysis of apoptotic cells}

To assess the degree of protection by MGF against 6-OHDA-induced apoptosis and necrosis, microscopic $\mathrm{AO} / \mathrm{EtBr}$ dual staining was used. Cells were differentiated into normal (live), apoptotic or necrotic from the uptake of $\mathrm{AO} / \mathrm{EtBr}$ stain. Normal (live) cells were seen as bright green colored nuclei with intact and uniform cell membrane. Apoptotic cells had orange to red nuclei with condensed or fragmented chromatin, whereas necrotic cells showed uniform orange to red nuclei. As expected, 6-OHDA largely induced apoptosis than necrosis (Fig. 2B). A significant $(\mathrm{p}<0.01)$ increase in apoptosis was observed in cells treated with 6-OHDA $(40 \mu \mathrm{M})$ alone for $24 \mathrm{~h}$ (Fig. 2B). MGF $(30 \mu \mathrm{M})$ alone treated cells showed no significant differences in the counts of live, apoptotic and necrotic cells when compared with vehicletreated control. On the other hand, incubation of cells with MGF $(30 \mu \mathrm{M})$ prior to 6-OHDA $(40 \mu \mathrm{M})$ for $24 \mathrm{~h}$ showed a marked decrease $(\mathrm{p}<0.01)$ in percent apoptosis, when compared with 6-OHDA control.

\section{Nitrite formation}

To assess the cytoprotective effect of MGF against 6-OHDA-induced toxicity, the extent of nitrite formation was measured in rat mesencephalic cells supernatant. Treatment of cells with $10-100 \mu \mathrm{M}$ of MGF alone did not alter the nitrite formation in these cells when compared with normal control group, while treatment of cells with 6-OHDA $(40 \mu \mathrm{M})$ showed

Fig. 2. Protective effect of mangiferin (MGF) on 6-OHDA-induced cytotoxicity in rat mesencephalic cells. (A) Cells were treated with $40 \mu \mathrm{M} 6-O H D A$ for $24 \mathrm{~h}$ in the absence or presence of MGF (10, 30 and $100 \mu \mathrm{M}$ ) and cytotoxicity was analyzed by MTT assay. The results are expressed as the mean \pm SEM of three independent experiments. ${ }^{a} p<0.01$ vs. normal control; ${ }^{b} p<0.01$ vs. 6 -OHDA40 $(\mu \mathrm{M})$. (B) MGF $(30 \mu \mathrm{M})$ reduces apoptosis and necrosis (assessed by acridine orange/ethidium bromide staining) in rat mesencephalic cells promoted by 6-OHDA $40(\mu \mathrm{M}) .{ }^{a} \mathrm{p}<0.01$ vs. normal control ${ }^{b} p<0.01$ vs. 6-OHDA $40(\mu \mathrm{M})$ normal; ${ }^{c} p<0.01$ vs. control apoptosis; ${ }^{d} p<0.01$ vs. 6-OHDA $40(\mu \mathrm{M})$ apoptosis. (C) MGF (10, 30 and $100 \mu \mathrm{M}$ ) decreases nitrite formation (analyzed by Griess reaction) in rat mesencephalic cells exposed to $40 \mu \mathrm{M}$ 6-OHDA for $24 \mathrm{~h}$. ${ }^{a} p<0.001$ vs. normal control; ${ }^{b} p<0.05$ vs. 6-OHDA $40(\mu \mathrm{M})$ (oneway ANOVA followed by Student Newman Keul's test) trite levels (Fig. 2C). This increase in nitrite levels by $6-O H D A$ was significantly $(\mathrm{p}<0.05)$ reduced by MGF (30 and $100 \mu \mathrm{M})$ pretreatment.

\section{Effect of MGF treatment on ketamine induced increase in IL-6 and MDA levels}

Treatment of animals with ketamine $(50 \mathrm{mg} / \mathrm{kg}$, twice a day, po, for 7 days) caused a significant increase 
$(\mathrm{p}<0.01)$ in the levels of IL-6 and MDA in brain tissues of schizophrenic group of animals when compared to normal control group. Pretreatment with MGF $(50 \mathrm{mg} / \mathrm{kg} /$ day, $p o$, for 7 days) significantly ( $\mathrm{p}<$ 0.05 ) reduced the ketamine associated elevation of IL-6 and MDA levels (Fig. 3A and B).
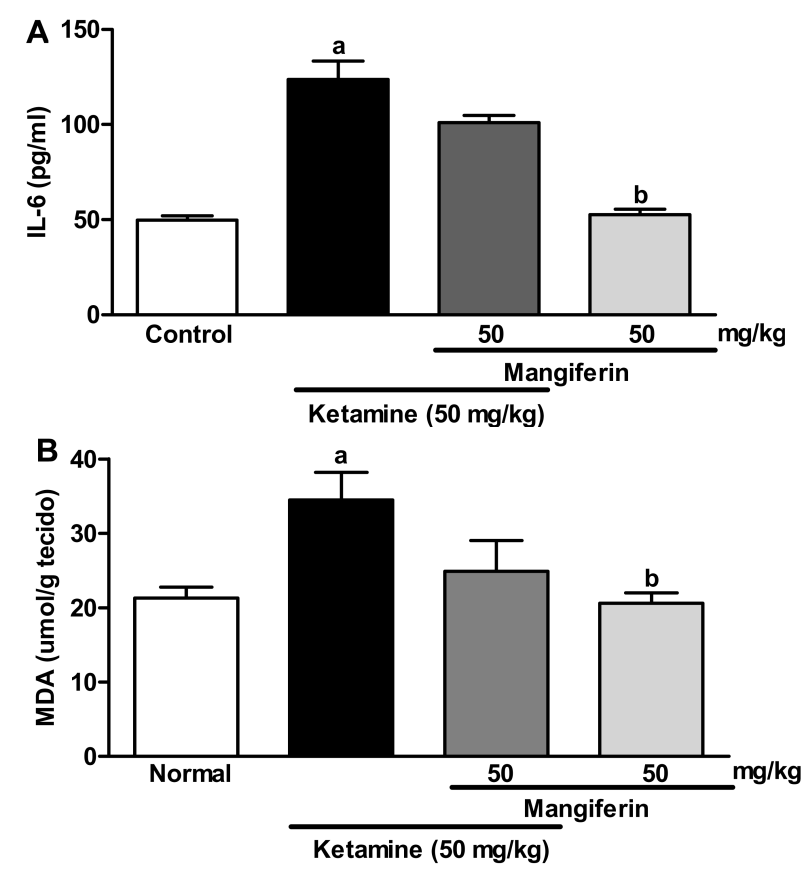

Fig. 3. Mangiferin (MGF) effects on brain tissue levels of cytokine IL-6 and MDA in normal and schizophrenic mice. Mice in groups ( $n=$ 8-10) were treated with vehicle (normal control; $2 \%$ DMSO in distilled water, $10 \mathrm{ml} / \mathrm{kg}$ ), MGF (50 mg/kg/day, po for 7 days) alone, ketamine (50 mg/kg, ip, twice a day for 7 days) alone or the combination of MGF + ketamine. After the end of 7-day treatment, all animals were sacrificed and whole brain tissues were carefully dissected from each animal and were homogenized to get 10\% homogenates. These homogenates were subjected to analysis of cytokine IL-6 (A) and malonaldialdehyde (MDA) (B) levels. The data are expressed as the mean \pm SEM of $8-10$ animals. ${ }^{a} p<0.01$ compared with vehicletreated control; ${ }^{b} p<0.01$ compared with ketamine (one-way ANOVA followed by Student Newman Keul's test)

\section{Effects of MGF treatment on changes in locomotor activity and behaviors}

The effects of treatments on behavioral changes induced by ketamine are shown in Table 1 . Neither MGF nor ketamine treated groups of mice showed a significant change in the number of invasions (entries) in open-field area. Treatment with ketamine caused a significant reduction $(\mathrm{p}<0.01)$ in rearing behavior of animals and MGF was unable to reverse the effect of ketamine. The group treated with ketamine showed significant increase $(p<0.05)$ in the number of grooming behavior, and the group pretreated with MGF reversed significantly $(p<0.05)$ this effect. The scores for stereotyped behavior of animals were significantly higher in all treated groups compared to control $(p<0.01)$. The group pretreated with MGF received a significantly lowered levels of scores as compared to ketamine alone $(\mathrm{p}<0.05)$, but unable to attain the levels seen in normal control.

\section{Discussion}

As expected, 6-OHDA inhibited cell viability in rat primary mesencephalic cell cultures. 6-OHDA is assumed to cause neuronal death by a free radicalmediated mechanism as well as by inhibiting the mitochondrial complex I and IV [18]. Our results show that 6-OHDA induced largely the apoptosis rather than necrosis, consistent with an earlier report [12]. MGF alone did not decrease the cell viability even when these cells were exposed to $100 \mu \mathrm{M}$ for $24 \mathrm{~h}$, indicating its non-toxic nature. Interestingly, when cells were pre-treated with MGF before the application of

Tab. 1. Effect of mangiferin treatment on locomotor behavioral changes in ketamine-induced schizophrenia model mice ${ }^{\infty}$

\begin{tabular}{lcccc}
\hline \multirow{2}{*}{ Groups } & \multicolumn{4}{c}{ Mouse behaviors $^{\S}$} \\
\cline { 2 - 4 } & Entries & Rearing & Grooming & Stereotyped \\
\hline Control & $61.17 \pm 4.05$ & $23.25 \pm 6.34$ & $37.00 \pm 4.72$ & $1.00 \pm 0.00$ \\
Ketamine & $50.71 \pm 4.86$ & $2.63 \pm 6.34^{\mathrm{a}}$ & $55.29 \pm 6.92^{\mathrm{a}}$ & $4.12 \pm 0.29^{\mathrm{a}}$ \\
Ketamine + mangiferin & $42.86 \pm 12.70$ & $1.00 \pm 0.76^{\mathrm{a}}$ & $37.00 \pm 6.16^{\mathrm{b}}$ & $3.43 \pm 0.20^{\mathrm{b}}$ \\
\hline
\end{tabular}

${ }^{\infty}$ Mice were treated with mangiferin (50 mg/kg/day, po, in $2 \%$ DMSO, for 7 days) followed by ketamine injections (50 mg/kg, ip, twice a day for 7 days) and locomotor behaviors were observed $30 \mathrm{~min}$ after the last injection, in an open-field test. $\$$ Values are the mean \pm SEM from a group of 8 animals. ${ }^{a} p<0.01$ vs. vehicle-treated control; ${ }^{b} p<0.05$ vs. ketamine alone. (one-way ANOVA followed by Student Newman Keul's test) 
6-OHDA, an increase in cell viability was observed, which was concentration-dependent and at $100 \mu \mathrm{M}$, its protection against 6-OHDA-induced cell death was almost total and equaled the normal control. MGF inhibited the apoptosis but showed no significant effect on necrosis. These findings corroborate the earlier studies that demonstrated the protective potential of MGF and antioxidants in general, against 6-OHDAinduced cytotoxicity in various cell lines and primary cultures $[37,42,46]$. A role for NO in the mitochondria-mediated apoptosis of dopaminergic neurons after 6-OHDA has recently been described [40]. We observed a significantly $(\mathrm{p}<0.05)$ attenuated apoptosis and a decreased NO increase caused by 6-OHDA. When mesencephalic cells rich in neuronal and nonneuronal cells were exposed to 6-OHDA, we observed a significant increase in NO associated with apoptosis, suggesting that NO promotes cell death. However, in mesencephalic cells preconditioned to MGF, NO production as well as cell death was markedly reduced, which indicates that MGF is cytoprotective.

The brain tissue is extremely sensitive to oxidative damage and oxidative stress can damage neurons and glial cells in a manner similar to other tissues via products of lipid peroxidation that are neurotoxic. Studies indicate that ketamine activates NADPHoxidase in brain and show that neuronal production of interleukin-6 (IL-6) is necessary for ketamine-mediated activation of NADPH-oxidase in brain [7]. Removal of IL- 6 in neuronal cultures by anti-IL-6 blocking antibodies, or in vivo by use of IL-6-deficient mice, prevented the increase in superoxide by ketamine and rescued the interneurons [7]. Our results demonstrate that oral administration of MGF $(50 \mathrm{mg} / \mathrm{kg})$ for 7 days could modulate ketamine induced impaired behaviors in particular, the grooming and stereotyped behaviors as well as the oxidative damage as indicated by increase in IL-6 level and lipid peroxidation in brain tissues of ketamine-induced schizhophrenia model mice. However, MGF was unable to reverse the rearing behavioral effect of ketamine that is possibly associated with strong sedation. MGF is a xanthone with various therapeutic activities including an antioxidant. It has been proposed that the catechol moiety with a 6,7-dihydroxylated structure, together with its aromatic bonds, is responsible for its antioxidant property [44]. MGF possibly acts as an effective anti-oxidant, mainly on account of its catechol moiety with a 6,7-dihydroxylated structure, which provides it the ability to neutralize reactive oxygen species gen- erated. MGF also has been shown to inhibit mitochondrial lipid peroxidation induced by $\mathrm{Fe}^{2+}$-citrate [3]. Thus, the observed significant reduction in IL-6 and the levels of lipid peroxidation product - malondialdehyde, indicates that MGF enhances antioxidant status, consistent with earlier reports that used other experimental models [13, 31, 45].

Studies indicate that MGF being a non-polar polyphenol can penetrate the blood brain barrier and has the potential to ameliorate the oxidative stress observed in neurodegenerative disorders [29] and MGF (20 mg/kg, po) has been proven to improve long-term cholinergic memory deficits by acetylcholinesterase (AChE) inhibition or cholinergic receptor stimulation and inhibition of $\mathrm{NF}-\kappa \mathrm{B}$ activation in vivo [27].

Ketamine, the NMDA channel antagonist that impairs the monoaminergic transmission is increasingly used to model the cognitive deficits and symptoms of schizophrenia [24]. To produce an animal model that simulates psychotic symptoms analogous to those in schizophrenic patients, subanesthetic doses of NMDA antagonist ketamine is often used $[15,14]$. In healthy volunteers, ketamine induces transient cognitive dysfunction, perceptual aberrations and changes reminiscent of the negative symptoms of schizophrenia, which relates to disorganized behavior, stereotyped movements and cognitive dysfunction in the rodent animal [20, 21]. Although how ketamine produces these negative symptoms of schizophrenia is unclear, investigational drugs that attenuate the effects of ketamine, may have therapeutic potential for treatment of psychiatric illnesses such as schizophrenia. In this study, an increased stereotyped activity and grooming with a decreased rearing as compared to controls were observed in mice treated subchronically with subanesthetic doses of ketamine $(50 \mathrm{mg} / \mathrm{kg}$, ip, twice a day for 7 days). In this context, studies in the past observed a lower density of glutamatergic receptors in brains of schizophrenic patients $[31,39]$ and a decreased glutamate receptor binding in subchronically ketaminetreated rat brains [5]. These findings justify the use of this ketamine animal model to screen novel compounds effective against schizophrenia [8]. Consequent to NMDA blockade by ketamine, other neuronal systems may get activated. For example, the depressant effect seen on rearing could have been due to sedation as ketamine has been shown to increase adenosine [31]. Ketamine may influence dopamine transmission [22]. Thus the observed changes in locomotor parameters might be a result of multiple me- 
chanisms. Nevertheless, mangiferin treatment overcomes some of the behavioral signs such as grooming and stereotyped activities in ketamine-induced schizophrenia mice.

The experimental models used in this study have some limitations such as the presence of neuronal and non-neuronal cells in rat primary mesencephalic cell cultures and the non-selectivity of ketamine to NMDA receptors affecting respiratory chain function in multiple brain regions including striatum, hippocampus and prefrontal cortex, which makes difficult to elucidate the precise protective mechanism of mangiferin. Nevertheless, mangiferin could counteract the oxidative stress promoted by 6-OHDA in mesencephalic cells in vitro and in ketamine-induced schizophrenia in vivo. Mangiferin might serve as a lead compound in developing drugs affective against schizophrenia and other neurodegenerative diseases.

To conclude, the present work indicated that mangiferin prevents cell death induced by 6-OHDA in rat primary mesencephalic cells, attenuates ketamine associated increase in cytokine IL- 6 cytokine and malondialdehyde formation in brain tissues, and ameliorates stereotyped movements, a characterstic of clinical schizophrenia. These findings suggest that mangiferin has a cytoprotective role, at least in part, related to its anti-inflammatory, anti-apoptotic and anti-lipid peroxidative potential plausibly because of its free radical scavenging and iron chelating ability, which could effectively reduce the oxidative stress.

\section{Conflict of interest statement:}

The authors declare that there are no conflicts of interest.

\section{Acknowledgments:}

We acknowledge the financial support from National Council of Technological and Scientific Development (CNPq) and Ceará Foundation for the Support of Scientific and Technological Development of the Ceará State (FUNCAP).

\section{References:}

1. Adibhatla RM, Hatcher JF: Lipid oxidation and peroxidation in CNS health and disease: from molecular mechanisms to therapeutic opportunities. Antioxid Redox Signal, 2010, 12, 125-169.

2. Amazzal L, Lapôtre A, Quignon F, Bagrel D: Mangiferin protects against 1-methyl-4-phenylpyridinium toxicity mediated by oxidative stress in N2A cells. Neurosci Lett, 2007, 418, 159-164.
3. Andreu GL, Delgado R, Velho J, Curti C, Vercesi AE: Iron complexing activity of mangiferin, a naturally occurring glucosylxanthone, inhibits mitochondrial lipid peroxidation induced by $\mathrm{Fe}^{2+}$-citrate. Eur J Pharmacol, 2005, 513, 47-55.

4. Barreto JC, Trevisan MT, Hull WE, Erben G, de Brito ES, Pfundstein B, Würtele $G$ et al.: Characterization and quantitation of polyphenolic compounds in bark, kernel, leaves, and peel of mango (Mangifera indica L.). J Agric Food Chem, 2008, 56, 5599-5610.

5. Becker A, Peters B, Schroeder H, Mann T, Huether G, Grecksch G: Ketamine-induced changes in rat behavior: A possible animal model of schizophrenia. Prog Neuropsychopharmacol Biol Psychiatry, 2003, 27, 687-700.

6. Beraki S, Kuzmin A, Tai F, Ogren SO: Repeated low dose of phencyclidine administration impairs spatial learning in mice: blockade by clozapine but not by haloperidol. Eur Neuropsychopharmacol, 2008, 18, 4869-4877.

7. Behrens MM, Ali SS, Dugan LL: Interleukin-6 mediates the increase in NADPH-oxidase in the ketamine model of schizophrenia. J Neurosci, 2008, 28, 13957-13966.

8. Bubeníková-Valesová V, Horácek J, Vrajová M, Höschl C: Models of schizophrenia in humans and animals based on inhibition of NMDA receptors. Neurosci Biobehav Rev, 2008, 32, 1014-1023.

9. Campos-Esparza MR, Sánchez-Gómez MV, Matute C: Molecular mechanisms of neuroprotection by two natural antioxidant polyphenols. Cell Calcium, 2009, 45, 358-368.

10. Carvalho AC, Guedes MM, de Souza AL, Trevisan MT, Lima AF, Santos FA, Rao VS: Gastroprotective effect of mangiferin, a xanthonoid from Mangifera indica, against gastric injury induced by ethanol and indomethacin in rodents. Planta Med, 2007, 73, 1372-1376.

11. Choi DW, Maulucci-Gedde MA, Kreigstein AR. Glutamate neurotoxicity in cortical cell culture. J Neurosci, 1987, 7, 357-368.

12. Choi WS, Yoon SY, Oh TH, Choi EJ, O’Malley KL, Oh YJ: Two distinct mechanisms are involved in 6-hydroxydopamine-and $\mathrm{MPP}^{+}$-induced dopaminergic neuronal cell death: role of caspasses, ROS, and JNK. J Neurosci Res, 1999, 57, 86-94.

13. Dar A, Faizi S, Naqvi S, Roome T, Zikr-ur-Rehman S, Ali M, Firdous S, Moin ST: Analgesic and antioxidant activity of mangiferin and its derivatives: the structure activity relationship. Biol Pharm Bull, 2005, 28, 596-600.

14. de Oliveira L, Fraga DB, De Luca RD, Canever L, Ghedim FV, Matos MP, Streck EL et al.: Behavioral changes and mitochondrial dysfunction in a rat model of schizophrenia induced by ketamine. Metab Brain Dis, 2011, 26, 69-77.

15. de Oliveira L, Spiazzi CM, Bortolin T, Canever L, Petronilho F, Mina FG, Dal-Pizzol F et al.: Different sub-anesthetic doses of ketamine increase oxidative stress in the brain of rats. Prog Neuropsychopharmacol Biol Psychiatry, 2009, 33, 1003-1008.

16. El-Seedi HR, El-Barbary MA, El-Ghorab DM, Bohlin L, Borg-Karlson AK, Göransson U, Verpoorte R: Recent insights into the biosynthesis and biological activities of natural xanthones. Curr Med Chem, 2010, 17, 854-901.

17. Gama CS, Salvador M, Andreazza AC, Lobato MI, Berk M, Kapczinski F, Belmonte-de-Abreu PS: Elevated se- 
rum thiobarbituric acid reactive substances in clinically symptomatic schizophrenic males. Neurosci Lett, 2008, 433, 270-273.

18. Glinka Y, Gassen M, Youdim MB: Mechanism of 6-hydroxydopamine neurotoxicity. J Neural Transm Suppl, 1997, 50, 55-56.

19. Green LC, Tanzenbaum SR, Goldman P: Nitrate synthesis in the germ free and conventional rat. Science, 1981, $212,56-58$.

20. Guha S, Ghosal S, Chattopadhyay U: Antitumor, immunomodulatory and anti-HIV effect of mangiferin, a naturally occurring glucosylxanthone. Chemotherapy, 1996, 42, 443-451.

21. Gunduz-Bruce H: The acute effects of NMDA antagonism: from the rodent to the human brain. Brain Res Rev, 2009, 60, 2798-2806.

22. Hetem LA, Danion JM, Diemunsch P, Brandt C: Effect of a subanesthetic dose of ketamine on memory and conscious awareness in healthy volunteers. Psychopharmacology (Berl), 2000, 152, 283-288.

23. Jung K, Lee B, Han SJ, Ryu JH, Kim DH: Mangiferin ameliorates scopolamine-induced learning deficits in mice. Biol Pharm Bull, 2009, 32, 242-246.

24. Kapur S, Seeman P: NMDA receptor antagonists ketamine and PCP have direct effects on the dopamine $\mathrm{D}_{2}$ and serotonin 5- $\mathrm{HT}_{2}$ receptors - implications for models of schizophrenia. Mol Psychiatry, 2002, 7, 837-844.

25. Lakhan SE, Vieira K: Schizophrenia pathophysiology: are we any closer to a complete model? Ann Gen Psychiatry, 2009, 8, 12.

26. Leiro JM, Alvarez E, Arranz JA, Siso IG, Orallo F: In vitro effects of mangiferin on superoxide concentrations and expression of the inducible nitric oxide synthase, tumour necrosis factor- $\alpha$ and transforming growth factor- $\beta$ genes. Biochem Pharmacol, 2003, 65, 1361-1371.

27. Lemus-Molina Y, Sánchez-Gómez MV, DelgadoHernández R, Matute C: Mangifera indica L. extract attenuates glutamate-induced neurotoxicity on rat cortical neurons. Neurotoxicology, 2009, 30, 1053-1058.

28. Liu WL, Bian S-Z, Gu Z-L, Jiang X-G, Guo C-Y, Zhao Y-B: Behavior study of ketamine-induced symptoms similar to schizophrenia in mice. J Forensic Med, 2009, $25,172-175$.

29. Mahmood D, Khanam R, Pillai KK, Akhtar M: Reversal of oxidative stress by histamine $\mathrm{H} 3$ receptor-ligands in experimental models of schizophrenia. Arzneimittelforschung, 2012, 62, 222-229.

30. Mahmood D, Khanam R, Pillai KK, Akhtar M: Protective effects of histamine $\mathrm{H}_{3}$-receptor ligands in schizophrenic behaviors in experimental models. Pharmacol Rep, 2012, 64, 191-204.

31. Mandryk M, Fidecka S, Poleszak E, Malec D: Participation of adenosine system in the ketamine-induced motor activity in mice. Pharmacol Rep, 2005, 57, 55-60.

32. Márquez L, García-Bueno B, Madrigal JL, Leza JC: Mangiferin decreases inflammation and oxidative damage in rat brain after stress. Eur J Nutr, 2012, 51, 729-739.

33. Martínez Sánchez G, Candelario-Jalil E, Giuliani A, León OS, Sam S, Delgado R, Núñez Sellés AJ: Mangif- era indica L. extract (QF808) reduces ischaemia-induced neuronal loss and oxidative damage in the gerbil brain. Free Radic Res, 2001, 35, 465-473.

34. McGohan AJ, Martin SJ, Bissonnette RP, Mahboubi A, Shi Y, Mogil RJ, Nishioka WK, Green DR: The end of the (cell) line: methods for the study of apoptosis in vitro. Methods Cell Biol, 1995, 46, 153-185.

35. Moghaddam B. Recent basic findings in support of excitatory amino acid hypotheses of schizophrenia. Prog Neuropsychopharmacol Biol Psychiatry, 1994, 18, 859-870.

36. Mosmann T: Rapid colorimetric assay for cellular growth and survival: application to proliferation and cytotoxicity assays. J. Immunol Methods, 1983, 65, 5-63.

37. Nobre Júnior HV, Cunha GM, Maia FD, Oliveira RA, Moraes MO, Rao VS: Catechin attenuates 6-hydroxydopamine (6-OHDA)-induced cell death in primary cultures of mesencephalic cells. Comp Biochem Physiol C Toxicol Pharmacol, 2003, 136, 175-180.

38. Ohkawa H, Ohishi N, Yagi K: Assay for lipid peroxides in animal tissues by thiobarbituric acid reaction. Anal Biochem, 1979, 95, 351-358.

39. Pardo Andreu GL, Maurmann N, Reolon GK, de Farias CB, Schwartsmann G, Delgado R, Roesler R: Mangiferin, a naturally occurring glucoxilxanthone improves long-term object recognition memory in rats. Eur J Pharmacol, 2010, 635, 124-128.

40. Renvoize C, Biola A, Pallardy M, Breard J: Apoptosis: identification of dying cells. Cell Biol Toxicol, 1998, 14, 111-120.

41. Setler P, Sarau H, McKinzie G: Differential attenuation of some effects of haloperidol in rats given scopalamine. Eur J Pharmacol, 1976, 39, 117-126.

42. Singh S, Kumar S, Dikshit M: Involvement of the mitochondrial apoptotic pathway and nitric oxide synthase in dopaminergic neuronal death induced by 6-hydroxydopamine and lipopolysaccharide. Redox Rep, 2010, 15, $115-122$.

43. Tsai G, van Kammen DP, Chen S, Kelley ME, Grier A, Coyle JT: Glutamatergic neurotransmission involves structural and clinical deficits of schizophrenia. Biol Psychiatry, 1998, 44, 667-674.

44. Wauthoz N, Balde A, Balde ES, Van Damme M, Duez P: Ethnopharmacology of Mangifera indica L. Bark and pharmacological studies of its main C-glucosylxanthone, mangiferin, Int J Biomed Pharm Sci, 2007, 1, 112-119.

45. Yoshikawa M, Ninomiya K, Shimoda H, Nishida N, Matsuda H: Hepatoprotective and antioxidative properties of Salacia reticulata: preventive effects of phenolic constituents on $\mathrm{CCl}_{4}$-induced liver injury in mice. Biol Pharm Bull, 2002, 25, 72-76.

46. Zhang ZJ, Cheang LC, Wang MW, Lee SM: Quercetin exerts a neuroprotective effect through inhibition of the iNOS/NO system and pro-inflammation gene expression in PC12 cells and in zebrafish. Int J Mol Med, 2011, 27, 195-203.

Received:July 31, 2011; in the revised form: April 4, 2012; accepted: April 23, 2012. 